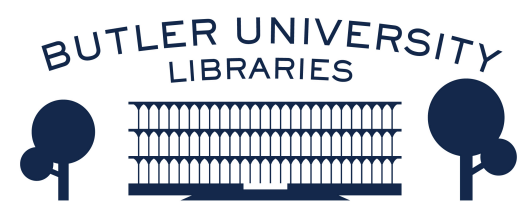

Journal of Hindu-Christian Studies

\title{
Book Review: To Be Cared For: The Power of Conversion and Foreignness of Belonging in an Indian Slum
}

James Elisha Taneti

International Theological Center, Atlanta

Follow this and additional works at: https://digitalcommons.butler.edu/jhcs

Part of the Christianity Commons, Hindu Studies Commons, and the Religious Thought, Theology and Philosophy of Religion Commons

\section{Recommended Citation}

Taneti, James Elisha (2017) "Book Review: To Be Cared For: The Power of Conversion and Foreignness of Belonging in an Indian Slum," Journal of Hindu-Christian Studies: Vol. 30, Article 19.

Available at: https://doi.org/10.7825/2164-6279.1671

The Journal of Hindu-Christian Studies is a publication of the Society for Hindu-Christian Studies. The digital version is made available by Digital Commons @ Butler University. For questions about the Journal or the Society, please contact cbauman@butler.edu. For more information about Digital Commons @ Butler University, please contact digitalscholarship@butler.edu. 
of widow remarriage radically transfigured Dalit women's lived experiences while subtly reinforcing high-caste projections of sexual promiscuity onto lower caste women. Gupta sees this internalization of early twentieth century high-caste Hindu narratives of femininity also reflected in the viranganacentered Dalit histories of 1857, which depict a balance of heroism and well-coiffed physiques familiar to any reader of popular, modern sanitized narratives of the Rani of Jhansi or Mirabai. Yet, the virangana narratives also carve Dalits into a national history that refuses dominant representations of their historic marginalization.

Gupta is careful to problematize falsely homogenizing identity categories such as "the Dalit woman," and she notes the plurality of regional and jati distinctions within the range of her study. This is underscored in her focus on the heterogeneous character of representations in the vernacular Hindi print archives, as well as in her emphasis on intimacy and quotidian rhythms within the sources. However, most of the print sources she consults are implicitly coded as male and the direct voices of Dalit women are rarely heard. Chapter 6, "Goddesses and Women's Songs," mitigates this by giving examples of vernacular songs composed by Dalit women in the kajli genre. Here the reader briefly glimpses a direct self-fashioning among Dalit women through their own compositions. However, with a few noted exceptions, these voices were recorded largely within the sphere of orality, outside of the textual sources that fill most of the study. The very absence of Dalit women's self-fashioning in the remainder of Gupta's sources does highlight her assertions of both the heterogeneous and yet reductionist nature of their prevailing representations in this period along the lines of both gender and caste.

Gupta's study is an excellent contribution that brings forward scholarly discussions on gender, caste, and the role of print media in the formation of publics, highlighting the necessity for intersectional approaches in the study of Indian history. It provides an accessible entrance into the subject that would work well in graduate seminars and professional contexts and could equally contribute to transregional conversations on the role of gender and class in revisionist historical studies.

Claire C. Robison

Denison University

\section{To Be Cared For: The Power of Conversion and Foreignness of Belonging in an Indian Slum. By Nathaniel Roberts. Oakland, CA: University of California Press, 2016, $\mathrm{xV}+312$ pages.}

KEEPING his word to the residents of a slum he called Anbu Nagar, Nathaniel Roberts eloquently and clearly interprets their world. Roberts tells us their story. He tells us everything, not just about their beliefs. With his lively narration and insightful commentary, he makes us understand their religion. Studying a slum in Chennai, India, Roberts, a gifted anthropologist and a Research Fellow at the Max Planck Institute for the Study of Religious and Ethnic 
Diversity, Germany, argues that longing to be cared for is the primary motive behind slum residents' conversion to Christianity. Also, worshipping a Christian god does not necessarily dislocate the converts from their slum community, he concludes.

An anthropologist residing with a community for an extended period to study it from within is not a novel idea. I am aware of the challenges of deciphering cultural codes of a community that an 'outsider' confronts. However, what sets Roberts apart from others are his humility to remain an outsider, willingness to share the natives' struggles, and familiarity with the vernacular. Roberts' transparency about his motives earned him natives' co-ownership in the project. A Dalit myself, I served in rural hamlets as well as urban slums, especially in Telugu-speaking slums of Chennai and Bangalore. The questions Roberts asked and insights he offered convinced me of the advantages an outsider has and the gifts he or she brings to the cultural anthropology. Roberts highlighted and carefully studied those aspects of slum life that a native would consider normal and ordinary. For example, as a native, I never paid attention to the gender basis and economic implications of the practice of chits among South Indian women.

In his analysis of how the slum residents define themselves in relation to the dominant society and the global community in Chapter 2, Roberts observes that the residents in this slum identify themselves more in terms of class than caste. He explains why they do not use caste identities in their self-definitions. Slum residents claim and take pride in their ability to care for others, an attribute that they use to distinguish themselves from the dominant segments in the city. Citing this goodness, the slum residents find and forge a sense of community with others beyond the national borders. In the following chapter, Robert contrasts residents' everyday ideals and "structural tensions." Even while granting women space to manage household economy, the notion of wifely auspiciousness puts blame on women for the financial and health maladies in the family. This chapter includes a fascinating analysis of the practices of money-lending and chits, an economic system of sharing resources among low-income women.

Chapter 4 offers a brilliant commentary on the contemporary debate on religious conversions in India, to which Roberts' book is a rich addition. Towards the end of the book, Roberts argues that the motives of slum residents' belief in Christian gods is not too different from their Hindu neighbors, as both seek from their gods material favors and protections. Slum Christians, however, differ from their neighbors in that they seek care from the Christian god and fellow Christians. Adherence to Christianity does not alienate them from their neighborhood, an argument the proponents of anti-conversion employ to oppose religious conversions to non-Hindu faiths. This chapter is so complete and comprehensive that I would recommend it to students interested in the study of conversion.

This analysis of century-long debate on conversion leaves proportionately less room for the voices of the converts compared to those of the dominant elite. Roberts astutely traces the impact of Mohandas Gandhi's contributions to the conversation and boldly questions his motives, using the yardstick that Gandhi used to judge his critics and converts. Roberts' discussion on Gandhi is ground-breaking and is a helpful echo to Joel Lee's work on Gandhi and 
Dalit conversions. It, however, falls prey to the temptation of giving Gandhi more space in the conversation than he deserves.

With this chapter, Roberts subtly but brilliantly locates the stories of slum Christians in the larger context of religious conversions in India. He prepares the reader to understand the slum religion he would discuss in the following three chapters. Readers unacquainted with the history of urbanization in India and migration of Dalits to the cities during the colonial era would have benefitted from a concise history of this slum and the roots of this slum religion.

The final three chapters explicate and interpret the religious world(s) of the slum residents. Roberts identifies the similarities between the beliefs of Hindu and Christian residents and highlights the fluidity of boundaries between the two. He also outlines the differences. He incisively defines what he means by these categories and delineates how different are these from Hinduisms and Christianities elsewhere. The use of simple binaries might sometimes exclude those residents who do not identify themselves as neither and refuse to worship Hindu and Christian gods. The discussion about pastoral authority and the rumors that surround them highlight the power dynamics in the slum religion. Parsing the prayers of the residents, Roberts examines the social significance of prayer. He then illustrates the theme of suffering and the countercultural ethos of slum Christianity with the story of Umbrella Preacher. Roberts deftly uses Rupa Viswanath's findings about Dalits' use of, or lack thereof, umbrellas a century ago to interpret Umbrella Preacher's religion and thus illustrates slum Christianity.

This book is a welcome addition to the conversations on conversions, especially in the light of anti-conversion legislations in India. Robert's keen observation of the world of the community under study and a critical appreciation towards it make this book credible. His incisive, lively and lucid writing style makes it readable and engaging. Nathaniel Roberts should be commended for this gift to the fields of religion in South Asia, World Christianity and Popular Hinduism.

James Elisha Taneti

International Theological Center, Atlanta

\section{Caste, Gender, and Christianity in Colonial India: Telugu Women in Mission. By James Elisha Taneti. New York: Palgrave Macmillan, 2013, 203 pages.}

HOW does one give voice to those whose own voices were historically marginalized or mostly unrecorded and whose significance therefore can easily go unacknowledged? Postcolonial history requires the best of the historian's abilities-to command archival material, to cautiously infer, to suggest, to apply intelligence and imagination, and to thereby offer plausible interpretations. This James Elisha Taneti does admirably in the 2013 installment in the Palgrave Macmillan's Postcolonialism and Religions series.

The text concerns itself with a category of Protestant church worker often mentioned but still under-examined. These are Biblewomen, women in the $19^{\text {th }}$ and first half of the $20^{\text {th }}$ 